\title{
Evidence of Monthly Anomalies in Pakistan Stock Exchange
}

\author{
Musarrat Shamshir, PhD \\ Associate Professor, Hamdard Institute of Education and Social Sciences \\ Hamdard University, Karachi, Pakistan \\ Mirza Jawwad Baig, PhD \\ Assistant Professor, Institute of Space and Planetary Astrophysics \\ University of Karachi, Pakistan \\ Khalid Mustafa, PhD \\ Professor, Department of Economics \\ University of Karachi, Pakistan
}

\begin{abstract}
The study is an extended effort to investigate the monthly anomalies across Pakistani stock market, on four stock indices of Pakistan stock exchange by using the data from previously known as Karachi stock exchange for the period from January 01, 2009 to August 31, 2014. The study is a unique attempt of its kind to include all four indices for exploring turn-of-the-month and month-ofthe-year effects with special consideration of tax-loss-selling hypothesis for the month of July for conventional January effect. Evidences of turn-of-the-month effect were found in indices except for KSE-30 and KMI-30 index. The study also found significant January returns evident in all four indices; however the effect cannot be contributed to tax-loss-selling hypothesis. Optimistic attitudes towards the year ahead and liquidity preference seem to be related with the heavy buying. July effect is found to exist in the market which may be contributed to tax-loss-selling hypothesis. Although, KSE-30 and KMI-30 indices were found to demonstrate atypical results as compared to the rest of the indices, yet it is concluded that stock market of Pakistan is not devoid of monthly anomalies.
\end{abstract}

Keywords: Pakistan stock exchange; Karachi stock exchange; Monthly anomalies; Tax-loss-selling; month-of-the year; turn-of-the month.

\section{INTRODUCTION}

The efficient market hypothesis (EMH) reflects the quickness of absorption and reflection of new information in the asset prices. It presumes the investor has an access to all available information and prices rapidly reflect the impact of all public information. New information in the market is assumed to be unpredictable and unsystematic; accordingly price movements are also irregular and random in an efficient market such that it assumes an equal chance of returns to investors. It implies that price fluctuations do not exhibit any trend and pattern and past prices cannot be taken as an instrument to predict the future prices and returns. The price movements in such a case is said to follow an unpredictable and unsystematic pattern called a 'random walk'. The said behavior shows evidences of indifferent-returns on stocks irrespective of size of the firm and the trading time, that is, returns are assumed to be homogenous across hours, days, weeks, months and years. However, for more than two decades in various financial markets of the world evidences of systematic patterns have been found. Such patterns may 
result higher or lower stock returns depending on, certain days, weeks and months. Anomalies may occur even in the markets with low volatility and high liquidity and present serious threats to classical asset pricing models. The traditional asset pricing model is inept to explain this observed fact. Since decades the researchers are relentlessly inquiring the factors which can capacitate such systematic pattern.

Among such patterns most recurrent and widely known include; size effects; reflecting higher returns associated with small sized firms as compared to the large ones (Rozeff \& Kinney, 1976; Banz, 1981; Keim, 1983; Roll, 1983); the seasonal or calendar effects including week-ofthe-month (WOM) effect (Ariel, 1987; Lakonishok \& Smidt, 1988), month-of-the-year (MOY) effect (Rozeff \& Kinney, 1976), turn-of-the-month (TOM) effect (Cadsby \& Ratner, 1992), the day-of-the-week (DOW) effect (Cross, 1973; French, 1980), and Islamic calendar effects (Mustafa, 2008). These effects have been tested internationally and diversified results can be found in various markets depending upon various institutional differences between developed and energent markets.

The presence of such systematic patterns in the stock market explain the violation of and divergence from efficient market hypothesis at least in weak-form market efficiency because asset prices movements are no more random but may be predicted on seasonal and calendar variations. These differences in returns may be far above or below than the normal and can affect investor in deciding their investment strategy, portfolio selection and portfolio management (Anwar \& Mulyadi, 2012). Technical analysts may develop strategies on the basis such predictable patterns to attract investor. This persuades the investors to follow such trading strategies which allow them to make abnormal profits in the markets (Yalcin \& Yucel, 2006). For example, investors may be willing to buy stocks on one specific day or month and sells on another based upon certain trend in the market on these specific periods in order to take the benefit of these effects. However, the materialization of these trends is questionable, as for these anomalies may arise only for a very short period and disappear strangely and the strategic action was taken before could end up in disaster instead. Moreover, the reappearance of such patterns is less likely to be repeated in the same form leaving the investor in vacillating risk-return management. Explicably a normal investor does not feel safe and encouraged to invest in the market with the presence of such phenomena. Therefore, uncovering these patterns in returns might benefit risk management and portfolio optimization of valued investors in the markets (Engle, 1993) on one hand and may contribute in strengthening of previous observed facts or producing contemporary empirical patterns of calendar dependencies.

Month-of-the-year effect is associated with higher returns in any one month than any other months during a year. (Rozeff \& Kinney, 1976) found seasonal pattern in an equal weighted index of New York Stock Exchange and found average monthly return on January are considerably higher (over one-third returns occurred in January alone) than during other months (January effect). January returns found higher as compared to remaining months in U.S. various other share markets (Rozeff \& Kinney, 1976; Keim, 1983; Lakonishok \& Smidt, 1984; Jaffe \& Westerfield, 1985a; 1985b). Furthermore, Keim (1983), Aggarwal et al. (1990) found higher January returns in small firms then the large firms thus establishing the phenomenon to small firms. However, Patel (2008) concluded that both developed and emerging stock markets do not exhibit a size effect or a reverse size effect and according to the study conducted by him on Indian stock market he further established that size gains are not evident to be influenced by January month returns. 
Another notion of the January effect appeared as tax-loss-selling (TLS) effect associated with a decrease in stock prices corollary to a major sell-off of stocks during the month of December; a strategy may be for counterbalancing the tax-loss on accrued capital gains, followed by an increase in buying during January. Although January effect has found to be diminishing in recent years, due to well-developed tax protection options become available with time, especially in seasoned capital markets. On the other hand, Haug \& Hirschey (2006) found persistence January effect in U.S. small stock returns despite of the Tax Reform Act of 1986. Moreover, the anomaly is persistently evident in emerging capital markets as these markets are found relatively less developed and less efficient than their developed counterparts.

Roll (1983) concluded that the higher volatility of small-cap firms pay them to observe significant short-term capital losses that can make investors to sell before the end of December. This selling pressure might lead to reduction on prices of small-cap stocks in the tax month, escorting a bounce back next month as a result of repurchase to replenish the investments.

According to Lakonishok \& Smidt (1988), turn-of-the-month (TOM) period is the duration between the last trading day of the previous month and first three trading days of the new month. Turn-of-the-month effect is associated with the temporarily increase in stock returns TOM period as compared to the rest-of-the-month (ROM) period. Increase of cash flow usually observed between the last two of the preceding and first three days of the new month. That increased liquidity may be connected to release of pension funds, interest payments and wages. Ariel (1987) examined Dow Jones and provided the evidence that days around the turnof-the month exhibit high rates of return. Cadsby \& Ratner, (1992) found turn-of-the-month effect evident in European, Canadian, US and emerging markets. Hensel \& Ziemba (1996) found TOM effects for S\&P 500, in a study carried out for daily returns between 1928-1993.

Several studies have been conducted to investigate the calendar anomalies on Karachi stock exchange (KSE). However, most of the studies were conducted on KSE-100 index leaving a major gap in the form of very little empirical work done on remaining indices belong to KSE such as KSE-30 index, all-share index and KMI-30 index. Amongst these; KSE-30 was introduced as a benchmark to determine the performance of stock market, KMI-30 consisted of firms which strictly meet the Sharia criteria, and all-share index takes all firms into consideration.

The selection criterion of listed companies in all four indices is based upon different methodologies; KSE-100 index and in all-share index both; the chronology is based upon market capitalization, but in case of former top 100 companies are selected, while in later; all firms are included in index. On the other hand selection of firms in KSE-30 and in KMI-30 is based upon free-float methodology and in KMI-30 index strictly Sharia compliant firms are included. Free float methodology may ensure the true liquidity of the shares in the stock market; therefore, is less expected to be handled by manipulators and hedgers and could be more reliable from the investors' point of view.

Hence, it is essential for the researchers to probe into calendar anomalies on all indices of Pakistani stock market, including traditional January effect in addition to turn-of-the-month and month-of-the-year effect. Shamshir \& Mustafa (2014a) examined DOW effects on Pakistani stock market and found DOW effects in KSE-100 and all-share index. The study further noted the contribution of free floating methodology for finding no evidences of DOW effects in KSE30 and KMI-30 index. 
This paper is an extension to the previous work by us and is focused to investigate monthly anomalies including turn-of-the-month, month-of-the-year effect and tax-loss-selling effect on Karachi stock exchange. The tax month is June in Pakistan; therefore it will be interesting to find July effect for the conventional January effect and higher returns of July, if found, could present a plausible explanation of TLS effect in Pakistani stock market.

The rationale of investigating tax-loss-selling effect in Pakistan is for two reasons; one, the effect has not been tested thoroughly before on Pakistani stock market provides; a major motivation behind the exploration. Two, the discussion on this intriguing phenomenon would continue to remain a major interest of financial researcher and trade analyst to find the possible explanations of its existence and non-existence even if ceases to appear with time.

Wage distribution period may be one of the determining factor of revising portfolio decsions. Investors with monthly wage distribution are expected to re-address their portfolios at the time of receiving wages. In Pakistan, wage distribution period is beween the last of the previous and first week of the susequent month. It is imparative therefore to determine the TOM effects for Pakistani markets as investor is more likely to make investment decsions between TOM periods.

In this particular study TOM period constitute one last trading day of the previous month plus first three trading days. The rest-of-the-month (ROM) period is defined as the remaining days (Lakonishok \& Smidt, 1988).

The study can be a major contribute in the finance literature and can benefit both; the investors when choosing any index among the four included in the study or a combination of indices for a diversified portfolio and risk management, and at the same time for trade analyst, while adopting appropriate trading strategies, if calendar anomalies are identified in any of the indices.

\section{LITERATURE REVIEW}

The phenomenon of stock market anomalies produces a great deal of inconsistent evidences and conflicting opinions by researchers and academicians. Black (1993) considered most of the anomalies as a result of data mining. In his opinion these anomalies vanishes as soon as they discovered and published.

In the words of Samuelson (1989),

"But of thousands of published and unpublished statistical testing of various forms of the efficient market hypothesis, a few dozen representing a minuscule percentage have isolated 10 pt milarly, Dimson \& Marsh (1998) presented evidences where anomaly disappears or gets reversed, once it gets publicized.

Furthermore, Roll \& Ross (1994) wrote,

"Over the past decade, I have attempted to exploit many of the seemingly most promising inefficiencies by actually trading significant amount of money... Many of these effects are surprisingly strong in the reported empirical work, but I have never yet found one that worked in practice".

On the contrary greater number of well-known literature provides evidences of persistent market anomalies that remained persistent over the decades from developed and developing world markets. Empirical evidence also suggested that even in the presence of anomalies 
investor is incapable to outperform for excess gains due to the high transaction and liquidity cost.

Among the early researches, Rozeff \& Kinney (1976) found evidence of monthly anomalies on the New York Stock Exchange. Keim (1983) found distinct January premiums and did not refute the negative relation between abnormal returns and size of the firm. He further noted that more than $50 \%$ of the excess premiums in the month of January came on the first trading day of the month. Brown et al. (1983) found excess returns associated to size evident in one period and disappeared with the time, suggested that the evidence of seasonal anomalies could be one of the factors of estimation methodologies. Reinganum (1983) further stated that small firms least likely to follow the TLS behavior although found to exhibit excess returns in January and related the January TLS hypothesis to large firms. Contrary to that, Gultekin \& Gultekin (1983) suggested irrelevancy of size with the-turn-of-the-year anomalies in US, UK and Australian markets. Lakonishok \& Smidt (1984) conducted long term study spreads over to 90 years and found persistent long-term turn-of-the-month, turn-of-the-year and other seasonal effects. Ariel (1987) found the mean distribution of returns higher in the first half of the month than in the second half. Aggarwal et al. (1990) also documented the seasonal effects in Tokyo stock market.

Cadsby \& Ratner (1992) presented the evidences of seasonal anomalies in European, Australian, and Canadian markets. Similar results were found in Japanese and Hong Kong markets. Roll (1993) argued that January anomaly in small sized firms is associated with TLS and explained that small-cap firms are more likely to at risk. Chang, Eric \& Pinegar (1986) documented January effect in the US market for long-term bonds. The same effect found to be negatively related with bond rating and positively related with firms associated with low quality bonds. The study further supports the January effect consistent with TLS. Jaffe \& Westerfield (1989) conducted a study to investigate the seasonal patterns in the stock markets of Australia, UK, Japan and Canada. The study confirms a distinctive seasonal pattern for each country with stronger 'last day of the month' effect. Brauer \& Chang (1990) identified the TLS as a possible explanation for January effect. They noted the returns to exhibit negative and positive relations to the mean returns of the preceding year and the standard deviations of their preceding year returns, respectively reflecting TLS effect in the January. Arsad \& Coutts (1997) supported the presence of weekend, January and holiday effects on Industrial Ordinary Shares Index when studied for the span of 60 years. The study found anomalies still concluded that the market may be incapable to be exploited for abnormal returns owing to the illiquidity and two side transaction cost of implementing trading strategies.

Recent literature produces mixed results regarding the existence of annual anomalies and excess returns in the market.

Coutts et al. (2000) investigated Athens stock market using ten years data set on banking, leasing and insurance sectors and found presence of weekend and January effects which gradually strengthened over time. He further noted that abnormal profits thus rendered after adjusting transaction cost do not affect the profitable strategies of investor, therefore offering the investor an efficient market situation.

Al-Khazali (2001) audited previous studies from 1926 to 1993 for seasonal effects in high-yield bond and confirmed the January effect and endorsed the appropriateness of statistical procedures adopted in previous studies. 
Sullivan et al. (2001) conducted a study that was focused to explore the effects of data mining on the occurrence of various anomalies; the possibility identified by Lakonishok \& Smidt (1988). They used the century data of daily returns and adopted the bootstrap technique that can separately measures the distortions in deducting inferences stimulated by data mining. They concluded that even significant calendar effects when are evaluated for certain rules set by investors and academicians seems to lose their significance to outperform the market to exploit abnormal returns.

Consistent with the work of Black (1993), and Dimson \& Marsh (1998); Marquering et al. (2006) advocated that anomalies if occur out of data snooping they are more likely to get disappeared after they get documented leaving the real anomalies continue to persist. They assumed that once the anomalies get reported and published by researchers and academicians, they get diluted and ceased to exist. The prospects and possibilities of strategies employed for exploiting abnormal profits thus die down gradually. The authors examined frequently occurring anomalies and found that very few anomalies still exist and many of them disappeared after the published awareness about them. Moreover, the study found the connection behind the timing of disappearance and reappearance of certain anomalies with the timing of respective publications about such anomalies.

Asteriou \& Kavetsos (2006) tested eight transition economies from 1991-2003 for seasonal effects. The study found significant January effect in Hungary, Poland and Romania, with a prominent evidence of TLS hypothesis in Hungary and Romania.

Similarly, Starks et al. (2006) supported the association of TLS hypothesis with January effect for municipal bond market. The study further indicated a strong tax selling behavior for the funds traded with the brokerage firms.

Moller \& Zilca (2008) investigated January effect across size deciles based on market capitalization on the monthly data from NYSE, AMEX and NASDAQ from 1927 to 2004. The study found short term January effect across deciles with significant higher returns in the first part of January and mean reversion in the second part of January.

Moosa (2007) examined Kuwait stock market and found monthly anomaly in June, on account of accumulating stocks in the month of June, before going to summer vacations, thus creating June effect. The results are consistent with the summer holiday effect previously found by AlSaad and Moosa (2005) as July anomaly.

He \& He (2011) related January effects with size before the Tax Reform Act of 1986, on US stock market. He found the shift of January effect to November effect after the tax reforms. The November effect was observed in both large and small-cap firms and therefore not related to size. Whilst, Haug \& Hirschey (2006) found January effect persistent in small firms in the US stock market.

Agnani \& Aray (2011) examined January effect across high and low volatility regimes distinguished by Markov switching model. The results revealed substantially larger magnitude of January effect in high volatility regime, although the number of significant coefficients is larger in low volatility regime. The study further revealed significant January effect for all size portfolios and hence concluded the absence of any correlation of January effect with portfolio size. The results of the study also support the diminishing January effect with time for all sizes. 
Depenchuk et al. (2010) examined the Ukrainian stock and bond markets to find monthly anomalies. The study found no evidence of January and weekend effects but strong TOM effect found to have existed in Ukrainian stock market.

Shamshir \& Mustafa (2014b) suggested the investigation of market anomalies using weekly and monthly stock returns.

Friday \& Hoang (2015) tested Vietnam Stock Exchange and support January effect for the entire period, while he concluded these effects are not explained by TLS.

\section{DATA AND METHODOLOGY}

The study is determining month-of-the-year anomaly focusing TLS hypothesis and turn-of-themonth anomaly on Pakistani stock exchange by using the data from previously known as Karachi stock exchange (KSE) for the period from January 01, 2009 to August 31, 2014. The study is using the daily closing prices of the four indices operating in the KSE market; KSE-100, KSE-30, KSE all-share and KMI-30 indices.

To proceed with the investigation of random walk we first calculate the return series of all the indices in the stock exchange. To focus on returns rather than on prices is due to two reasons. First, since the financial markets are considered to be the close to perfect competition therefore the size of investment does not influence prices. Secondly, the returns are more attractive from the perspective of investor and at the same time more appropriate to fulfill the approach statistical analysis than prices.

Volatility is highly persistent in KSE-100 index and least persistent in KSE-30 index; two most traded indices of Pakistani stock market (Shamshir \& Mustafa, 2014a).

The null hypothesis of equal monthly returns is used to examine monthly anomaly and TLS effect. For examining of month-of-the-year and turn-of-the-month effect stock returns first descriptive statistics will be examined to observe the MOY, TOM and ROM period mean returns and the way standard deviation is related to mean returns.

The dummy variable approach in regression is being used here where each individual dummy variable accounts for the excess return for the particular month for investigating MOY effect (Equation 1) and TLS effect. Similarly, in case of examining TOM effect (Equation 2) the dummy variable accounts for the excess return for the TOM period with null hypothesis of zero difference in returns between TOM and ROM period (Lakonishok \& Smidt, 1988; Cadsby \& Ratner, 1992).

$$
\begin{array}{ll}
R_{t}=\sum_{i=1}^{12} \gamma_{i} D_{i t}+\varepsilon_{t} & \text { Equation } 1 \\
R_{t}=\alpha_{1} D_{R O M t}+\alpha_{2} D_{\text {TOM }}+\varepsilon_{t} & \text { Equation } 2 \\
\text { Where } & \\
t=1,2, \ldots T & \\
R_{t}=\text { Stock return on an index at time t. } & \\
D_{i t}: \text { Dummy variable corresponding to } 12 \text { months } \\
D_{\text {TOMt }}: \text { Dummy variable corresponding to TOM days } \\
D_{R O M t}: \text { Dummy variable corresponding to ROM days } \\
\varepsilon_{t} \text { Random disturbance term } \varepsilon_{t} \sim N(0,1)
\end{array}
$$




\section{Descriptive Statistics of Monthly Returns}

\section{ANALYSIS AND RESULTS}

Table 1, below reflects the descriptive statistics of monthly returns. Results indicate mostly positive mean returns in all months with highest during March and July. The value of standard deviation is highest (0.1387) in case of KMI-30 index in the month of February. Negative mean returns are evident for the month of May while positive higher can be seen for the month of July. Low and mostly negative returns in May indicate large selling and higher and mostly positive returns in July signify large buying in July. The higher returns in July may be attributed to the same reason as in January effect where higher returns in January may be ascribed to more buying following a sell-off occurred during the month of December to compensate the tax losses.

Table 1: Descriptive Statistics of Monthly Returns

\begin{tabular}{|c|c|c|c|c|c|c|c|c|}
\hline & \multicolumn{2}{|l}{ KSE-100 Index } & \multicolumn{2}{|c|}{ KSE-30 Index } & \multicolumn{2}{|c|}{ KSE-All share } & \multicolumn{2}{|c|}{ KMI-30 Index } \\
\hline & Mean & SD & Mean & SD & Mean & SD & Mean & SD \\
\hline Jan & -0.0004 & 0.0150 & 0.0006 & 0.0181 & -0.0004 & 0.0141 & 0.0020 & 0.0163 \\
\hline Feb & 0.0010 & 0.0117 & 0.0014 & 0.0142 & 0.0008 & 0.0111 & 0.0012 & 0.1387 \\
\hline Mar & 0.0034 & 0.0140 & 0.0031 & 0.0158 & 0.0032 & 0.0132 & 0.0041 & 0.0144 \\
\hline Apr & 0.0016 & 0.0133 & 0.0011 & 0.0153 & 0.0015 & 0.0130 & 0.0016 & 0.0144 \\
\hline May & -0.0003 & 0.0111 & -0.0004 & 0.0501 & -0.0004 & 0.0536 & 0.0002 & 0.0108 \\
\hline Jun & 0.0008 & 0.0103 & 0.0001 & 0.0125 & 0.0007 & 0.0101 & 0.0005 & 0.0101 \\
\hline Jul & 0.0028 & 0.0088 & 0.0033 & 0.0101 & 0.0026 & 0.0082 & 0.0033 & 0.0086 \\
\hline Aug & 0.0001 & 0.0126 & 0.0000 & 0.0141 & 0.0000 & 0.0122 & 0.0005 & 0.0826 \\
\hline Sep & 0.0021 & 0.0110 & 0.0013 & 0.0125 & 0.0020 & 0.0105 & 0.0018 & 0.0113 \\
\hline Oct & 0.0010 & 0.0109 & 0.0003 & 0.0124 & 0.0008 & 0.0103 & 0.0012 & 0.0120 \\
\hline Nov & 0.0015 & 0.0092 & 0.0011 & 0.0106 & 0.0017 & 0.0089 & 0.0017 & 0.0096 \\
\hline Dec & 0.0015 & 0.0078 & 0.0010 & 0.0089 & 0.0015 & 0.0075 & 0.0013 & 0.0079 \\
\hline
\end{tabular}

OLS Results for the Month-of-the-year Analysis

Table 2, below in showing regression results reveals the significant January effect in the market, which can be attributed year-end cash flows arising from debt contracts redemption. Another plausible explanation is the investors' optimism and confidence on the market for new-year investment resolution. It is to be noted that January seasonal is not credited to TLS hypothesis, owing to June as tax month in Pakistan. Table 2, also indicates June negative returns and July positive returns in all four indices. Moreover, significant July effect is very obvious in KMI-30 index implicating TLS related July effect. 
Table 2: OLS Results for the Month-of-the-year Analysis

\begin{tabular}{|c|c|c|c|c|c|c|c|c|}
\hline & \multicolumn{4}{|c|}{ KSE-100 Index } & \multicolumn{4}{c|}{ KSE-30 Index } \\
\hline & Coeff. & Std. & t-stat & Prob. & Coeff. & Std. & t-stat & Prob. \\
\hline Jan & 0.6982 & 0.1542 & 4.5269 & 0.0000 & 0.8067 & 0.1486 & 5.4302 & 0.0000 \\
\hline Feb & -0.0311 & 0.2290 & -0.1357 & 0.8924 & -0.0328 & 0.2192 & -0.1498 & 0.8813 \\
\hline Mar & -0.1074 & 0.1668 & -0.6440 & 0.5214 & -0.0411 & 0.1747 & -0.2356 & 0.8144 \\
\hline Apr & -0.0651 & 0.1878 & -0.3465 & 0.7298 & -0.1221 & 0.1945 & -0.6282 & 0.5316 \\
\hline May & 0.1324 & 0.1977 & 0.6698 & 0.5049 & 0.0281 & 0.0505 & 0.5568 & 0.5792 \\
\hline Jun & -0.1984 & 0.2181 & -0.9096 & 0.3657 & -0.1952 & 0.2105 & -0.9273 & 0.3564 \\
\hline Jul & 0.2586 & 0.2559 & 1.0104 & 0.3152 & 0.3407 & 0.2533 & 1.3448 & 0.1823 \\
\hline Aug & 0.0453 & 0.1767 & 0.2565 & 0.7982 & 0.0084 & 0.1857 & 0.0454 & 0.9639 \\
\hline Sep & -0.0218 & 0.2021 & -0.1079 & 0.9143 & -0.0450 & 0.2126 & -0.2116 & 0.8330 \\
\hline Oct & 0.1865 & 0.2113 & 0.8826 & 0.3800 & 0.0887 & 0.2226 & 0.3986 & 0.6912 \\
\hline Nov & 0.2210 & 0.2697 & 0.8197 & 0.4147 & 0.2573 & 0.2626 & 0.9798 & 0.3300 \\
\hline Dec & -0.0158 & 0.3054 & -0.0519 & 0.9588 & -0.0818 & 0.3038 & -0.2692 & 0.7884 \\
\hline
\end{tabular}

Table 2: OLS Results for the Month-of-the-year Analysis (Contd.)

\begin{tabular}{|c|c|c|c|c|c|c|c|c|}
\hline & \multicolumn{4}{|c|}{ KSE-All share Index } & \multicolumn{4}{c|}{ KMI-30 Index } \\
\hline & Coeff. & Std. & t-stat & Prob. & Coeff. & Std. & t-stat & Prob. \\
\hline Jan & 0.6753 & 0.1572 & 4.2945 & 0.0000 & 0.7243 & 0.1449 & 4.9995 & 0.0000 \\
\hline Feb & 0.0024 & 0.2285 & 0.0107 & 0.9915 & 0.0279 & 0.0189 & 1.4727 & 0.1447 \\
\hline Mar & -0.1255 & 0.1680 & -0.7471 & 0.4571 & -0.0878 & 0.1579 & -0.5558 & 0.5798 \\
\hline Apr & -0.0912 & 0.1824 & -0.5000 & 0.6184 & -0.1271 & 0.1772 & -0.7177 & 0.4750 \\
\hline May & -0.0051 & 0.0393 & -0.1295 & 0.8973 & 0.1661 & 0.2181 & 0.7615 & 0.4485 \\
\hline Jun & -0.1845 & 0.2164 & -0.8526 & 0.3963 & -0.2449 & 0.2321 & -1.0552 & 0.2944 \\
\hline Jul & 0.2611 & 0.2663 & 0.9805 & 0.3297 & 0.5852 & 0.2683 & 2.1812 & 0.0320 \\
\hline Aug & 0.0352 & 0.1752 & 0.2011 & 0.8411 & 0.0217 & 0.0321 & 0.6776 & 0.4999 \\
\hline Sep & -0.0135 & 0.2040 & -0.0660 & 0.9476 & 0.0904 & 0.2067 & 0.4376 & 0.6628 \\
\hline Oct & 0.1847 & 0.2133 & 0.8658 & 0.3891 & 0.2117 & 0.1960 & 1.0801 & 0.2833 \\
\hline Nov & 0.2364 & 0.2677 & 0.8830 & 0.3798 & 0.2433 & 0.2529 & 0.9621 & 0.3388 \\
\hline Dec & 0.0425 & 0.3029 & 0.1402 & 0.8889 & -0.1788 & 0.3033 & -0.5896 & 0.5571 \\
\hline
\end{tabular}


Table 3: Descriptive Statistics of TOM and ROM period Returns on KSE Indices

\begin{tabular}{|c|c|c|c|}
\hline & & Mean & $\begin{array}{l}\text { Std. } \\
\text { Dev. }\end{array}$ \\
\hline \multirow{2}{*}{$\begin{array}{l}\text { KSE-100 } \\
\text { Index }\end{array}$} & TOM & 0.0032 & 0.0100 \\
\hline & ROM & 0.0006 & 0.0100 \\
\hline \multirow{2}{*}{$\begin{array}{l}\text { KSE-30 } \\
\text { Index }\end{array}$} & TOM & 0.0042 & 0.0200 \\
\hline & ROM & 0.0263 & 0.5100 \\
\hline \multirow{2}{*}{$\begin{array}{l}\text { KSE-All } \\
\text { Share } \\
\text { Index }\end{array}$} & TOM & 0.0026 & 0.0100 \\
\hline & ROM & 0.0007 & 0.0200 \\
\hline \multirow{2}{*}{$\begin{array}{l}\text { KMI-30 } \\
\text { Index }\end{array}$} & TOM & 0.0035 & 0.0100 \\
\hline & ROM & 0.0009 & 0.0500 \\
\hline
\end{tabular}

Table 3, exhibits the descriptive statistics of TOM days; one last trading day of the previous month plus three first trading days of the next month and ROM days; the-rest-of-the-month days. Table 3, also depicts positive mean returns in both TOM and ROM period in KSE indices however, significantly higher mean returns in TOM period than the rest of the days, except for KSE-30 index. These finding are consistent with the results of Lakoniskok and Smidt (1988). For KSE- 30, TOM effect seems to be absent with high mean return value and high risk during ROM days.

Table 4: OLS Results for Turn-of-the-month Analysis

\begin{tabular}{|c|c|c|c|c|c|}
\hline & & Coeff. & Std. & T-stats. & Prob. \\
\hline $\begin{array}{c}\text { KSE- } \\
\mathbf{1 0 0} \\
\text { Index }\end{array}$ & TOM & 0.0031 & 0.0007 & 4.5934 & 0.0000 \\
\cline { 2 - 6 } & ROM & 0.0007 & 0.0003 & 1.9960 & 0.0461 \\
\hline $\begin{array}{c}\text { KSE- } \\
\text { 30 } \\
\text { Index }\end{array}$ & TOM & 0.0042 & 0.0277 & 0.1518 & 0.8794 \\
\cline { 2 - 6 } & ROM & 0.0263 & 0.0136 & 1.9388 & 0.0527 \\
\hline $\begin{array}{c}\text { KSE- } \\
\text { All } \\
\text { share } \\
\text { index }\end{array}$ & TOM & 0.0026 & 0.0010 & 2.4508 & 0.0144 \\
\cline { 2 - 6 } & ROM & 0.0007 & 0.0005 & 1.4641 & 0.1434 \\
\hline \multirow{2}{*}{$\begin{array}{c}\text { KMI- } \\
30\end{array}$} & TOM & 0.0035 & 0.0026 & 1.3457 & 0.1786 \\
\cline { 2 - 6 } $\begin{array}{c}\text { Index }\end{array}$ & ROM & 0.0009 & 0.0013 & 0.6873 & 0.4920 \\
\hline
\end{tabular}


Table 4, illustrates the OLS results with TOM and ROM as dummy variables in the model. Results reveal significant TOM effect in the stock market. TOM effects are found to be significant at 5\% or lower level in KSE-100, and KSE-all share. However, in case of KSE-30 and KMI-30 indices no TOM effects are found during the study period. The absence of turn-of-themonth can be contributed to the free floating methodology of shares employed in KSE-30 and KMI-30 indices. Shamshir and Mustafa (2014a) also concluded that absence of day-of-theweek anomaly for KSE-30 and KMI-30 index is associated with the free floating methodology of shares in these indices.

\section{SUMMARY AND CONCLUSION}

This paper is focused to investigate monthly anomalies including turn-of-the-month, month-ofthe-year effect and tax-loss-selling effect on Pakistan stock exchange, by using the data of previously known Karachi stock exchange. The tax month is June in Pakistan; therefore, the study was more interested in finding July effect for conventional January effect associated with TLS.

The dummy variable approach in regression was applied where each individual dummy variable accounts for the excess return for the particular month for investigating MOY effect and TLS effect. Similarly, for examining TOM effect, the dummy variable accounts for the excess return for the TOM period with null hypothesis of zero difference in returns between TOM and ROM period.

The study found significant January returns evident in all four indices; however the upsurge in returns cannot be credited to TLS hypothesis but may be attributed to psychology of the investor;

The optimism and confidence linked with new-year resolution. Moreover, buying elevation also explains the liquidity preference approach of investors reflected in investment management strategies for the year to proceed.

Negative June returns and positive July returns explains the July effect synonymic to traditional January effect reflecting conventional TLS strategies of investor, concluding the presence of such an effect in Pakistan stock exchange.

Similarly, TOM effects are found with the significant t-statistics, concluding higher returns associated with greater cash flow in TOM defined periods. However, TOM effect could not be found KSE-30 and KMI-30 index.

Although, KSE-30 and KMI-30 indices were found to demonstrate atypical results as compared to the rest of the indices, yet it is concluded that stock market of Pakistan is not devoid of monthly anomalies.

\section{References}

Aggarwal, R., Rao, R. P., \& Hiraki, T. (1990). Regularities in Tokyo Stock Exchange Security Returns: P/E, Size and Seasonal Influences. Journal of Financial Research, 13 (3), 249-263.

Agnani, B., \& Aray, H. (2011). The January Effect Across Volatility Regimes. Quantitative Finance, 11 (6), $947-953$. Al-Khazali, O. M. (2001). Does the January Effect exist in High-Yield Bond Market? Review of Financial Economics, 10, 71-80. 
Anwar, Y., \& Mulyadi, M. S. (2012). Anwar, Y., \& Mulyadi, M. S. Analysis of Caendar Effects: Day-of-the-week effects in Indonesia, Singapore, and Malaysia Stock Markets. African Journal of Business Management, 6 (11), $3880-3887$.

Ariel, R. A. (1987). A Monthly Effect in Stock Returns. Journal of Financial Economics, 18, 161-174.

Arsad, Z., \& Coutts, A. J. (1997). Security price anomalies in the London International Stock Exchange: a 60 year perspective. Applied Financial Economics, 7 (5), 455-464.

Asteriou, D., \& Kavetsos, G. (2006). Testing for the existence of the January effect in transition economies. Applied Financial Economics Letters, 2 (6), 375-381.

Banz, W. R. (1981). The relationship between return and market value of common stocks. Journal of Financial Economics, 9 (1), 3-18.

Black, F. (1993). Beta and Return. The Journal of Portfolio Management, 20 (1), 8-18.

Brauer, G. A., \& Chang, E. C. (1990). Return seasonality in stocks and their underlying assets: tax-loss selling Versus Information Explanations. Review of Financial Studies, 3 (2), 255-280.

Brown, P., Kleidon, A. W., \& Marsh, T. A. (1983). New Evidence on the Nature of Size-Related Anomalies in Stock prices. Journal of Financial Economics, 12, 33-56.

Cadsby, C. B., \& Ratner, M. (1992). Turn-of-month and pre-holiday effects on stock returns: Some international evidence. Journal of Banking \& Finance, 16 (3), 497-509.

Chang, E. C., \& Pinegar, J. M. (1986). Return Seasonality and Tax-Loss Selling in the Market for Long-Term Government and Corporate Bonds. Journal of Financial Economics, 17, 391-415.

Coutts, A., Kaplanidis, C., \& Rob, J. (2000). Security price anomalies in an emerging market: the case of the Athens Stock Exchange. Applied Financial Economics, 10 (5), 561-571.

Cross, F. (1973). The Behavior of Stock Prices on Fridays and Mondays. Financial Analysts Journal, 29 (6), $67-69$.

Depenchuk, I. O., Compton, W. S., \& Kunkel, R. A. (2010). Ukrainian financial markets: an examination of calendar anomalies. Managerial Finance, 36, 502 - 510.

Engle, R. F. (1993). Statistical Models for Financial Volatility. Financial Analysts Journal, 49 (1), 72-78.

French, K. R. (1980). Stock returns and the weekend effect. Journal of Financial Economics, 8 (1), 55-69.

Friday, S. H., \& Hoang, N. (2015). Seasonality in the Vietnam Stock Index. The International Journal of Business and Finance Research, 9 (1), 103-112.

Gultekin, M. N., \& Gultekin, B. N. (1983). Stock market Seasonality: International Evidence. Journal of Financial Economics, 12, 469-481.

Haug, M., \& Hirschey, M. (2006). Mark Haug and Mark HirscheyThe January Effect. Financial Analysts Journal, 62 (5), 78-88.

He, L. T., \& He, S. C. (2011). Has the November Effect Replaced the January Effect in Stock Markets? Managerial and Decision Economics, 32, 481-486.

Hensel, C. R., \& Ziemba, W. T. (1996). Investment Results from Exploiting Turn-of-the-Month Effects. The Jounal of Portfolio Management, 22 (3), 17-23.

Jaffe, J., \& Westerfield, R. (1989). Is there a Monthly Effect in Stock Market Returns? Evidence from Foreign Countries. Journal of Banking and Finance, 13, 237-244.

Jaffe, J., \& Westerfield, R. (1985b). Patterns in Japanese Common Stock Returns: Day of the Week and Turn of the Year Effects. Journal of Financial and Quantitative Analysis, 20 (2), 261-272.

Jaffe, J., \& Westerfield, R. (1985a). The Weekend Effect in Common Stock Market Returns: The International Evidence. Journal of Finance, 40 (2), 433-454.

Keim, D. B. (1983). Size related anomalies and Stock Return Seasonality: Further Empirical Evidence. Journal of Financial Economics, 12, 13-32.

Lakonishok, J., \& Smidt, S. (1988). Are Seasonal Anomalies Real? A Ninety-Year Perspective. The Review of Financial Studies, 1 (4), 403-425. 
Marquering, W., Nisser, J., \& Valla, T. (2006). Disappearing anomalies: A dynamic analysis of the persistence. Applied Financial Economics, 16 (4), 291-302.

Moller, N., \& Zilca, S. (2008). The evolution of the January effect. Journal of Banking \& Finance, 32, 447-457.

Moosa, A. I., \& Husain, A.-M. (2007). The Profitability of Trading Rules and Volatility in Emerging Financial Markets. Hyderabad, India: Icfai University Press.

Mustafa, K. (2008). The Islamic Calendar Effect on Karachi Stock Market. 8th International Business Research Conference. Dubai.

Patel, J. B. (2016). The January Effect Anomaly Reexamined In Stock Returns. The Journal of Applied Business Research, 32 (1), 317-324.

Reinganum, M. R. (1983). The anomalous stock market behavior of small firms in January: Empirical tests for taxloss. Journal of Financial Economics, 12 (1), 89-104.

Roll, R. (1983). On computing mean returns and the small firm premium. Journal of Financial Economics, 12 (3), 371-386.

Roll, R., \& Ross, S. A. (1994). On the Cross-sectional Relation between Expected Returns and Betas. The Journal of Finance, 49 (1), 101-121.

Rozeff, S. M., \& Kinney Jr., W. R. (1976). Capital market seasonality: The case of stock returns. Journal of Financial Economics, 3 (4), 379-402.

Samuelson, P. A. (1989). The judgment of economic science on rational portfolio management Indexing, timing, and long-horizon effects. The Journal of Portfolio Management, 16 (1), 4-12.

Shamshir, M., \& Mustafa, K. (2014b). Efficiency in Stock Markets: A Review of Literature. International Journal of Economics, Commerce and Management, 2 (12), 1-21.

Shamshir, M., \& Mustafa, K. (2014a). Presence of Day-of-the-week Effect in the Karachi Stock Exchange. Research Journal of Finance and Accounting, 5 (19), 47-58.

Starks, L. T., Yong, L., \& Zheng, L. (2006). Tax-loss selling and the January effect: Evidence from municipal bond closed-end funds. The Journal of Finance, 61 (6), 3049-3067.

Sullivan, R., Timmermann, A., \& White, H. (2001). Dangers of data mining: The case of calendar effects in stock returns. Journal of Econometrics, 105, 249-286.

Yalcin, Y., \& Yucel, M. E. (2006). The Day-of-the-Week Effect on Stock-Market Volatility and Return: Evidence from Emerging Markets. Czech Journal of Economics and Finance, 56 (5-6), 258-279. 